\title{
Regulation of leukocyte interleukin 2 and interleukin 2 receptor gene expression by rabbit blastocoelic fluid
}

\author{
D. Bergeron ${ }^{1}$, M. Audette ${ }^{2}$ and R. D. Lambert ${ }^{1 *}$ \\ ${ }^{1}$ Departments of Obstetrics and Gynecology, Laval University and Ontogénie et Reproduction, CHUL \\ Research Center, Ste-Foy, Québec, Canada GIV 4G2; and ' Endocrinologie Moléculaire Research Unit, \\ CHUL Research Center, Ste-Foy, Québec, Canada G1V 4G2
}

\begin{abstract}
The mechanisms underlying the inhibition of lymphocyte proliferative response by rabbit blastocoelic fluid collected on day 12 of embryonic development were investigated. Treatment with blastocoelic fluid, even in the presence of concanavalin A, maintains lymphocytes in a quiescent state by preventing cell entry into the $S$ phase of the cell cycle. Gene expression of interleukin 2 receptor is completely blocked by treatment with blastocoelic fluid as are the secretion and gene expression of interleukin 2. Addition of interleukin 2 to prestimulated interleukin 2 receptor positive lymphocytes failed to downregulate the expression of high-affinity interleukin 2 receptor and completely abolished the embryonic fluid-mediated inhibitory effect on $\left[{ }^{3} \mathrm{H}\right]$ thymidine incorporation. Taken together, these results suggest that embryonic fluid has differential inhibitory effects, depending on the activation state of the lymphocytes. Nevertheless, inhibition of interleukin 2 and interleukin 2 receptor expression by embryonic fluid restrains immune cell activity and therefore can be implicated in the survival of the fetal semi-allograft.
\end{abstract}

\section{Introduction}

Implantation of embryos in certain mammals, such as humans and rabbits, involves cell fusion between the embryo and the uterine endometrial cells, which favours embryo-uterine exchanges (Schlafke and Enders, 1975; Morin et al., 1992). A significant accumulation of leukocytes in the newly formed decidua has been demonstrated (Clark et al., 1984) in some animals (including rats, mice and humans; see Stewart, 1991, for a review), leading to close contact between the embryonic trophoblast and the maternal immune system. Thus, despite the fact that trophoblastic MHC class I antigens are apparently not in direct contact with maternal blood (Redman et al., 1984; Hunt et al., 1988), embryos are exposed to maternal immune cells in the decidua, such as natural killer (NK)-like cells (Croy et al., 1985; Gambel et al., 1985), which have been associated with spontaneous abortions in mice (de Fougerolles and Baines, 1987; Gendron and Baines, 1988; Zheng et al., 1993). Even if they are naturally resistant to NK cells in vitro, human and mouse trophoblastic cells have been shown to be killed by lymphocyte-activated killer (LAK) cells (Drake and Head, 1989; King and Loke, 1990). Because the uterus is, therefore, a potentially hostile environment for the embryo, immunological rejection could be expected.

It is our hypothesis that, to avoid such a disastrous fate, the embryo must locally regulate the maternal immune system. This could be accomplished in several ways: local accumulation of suppressor T cells (Clark et al., 1984), an absence of major histocompatibility complex (MHC) class II antigens (Redman

*Correspondence and reprint requests.

Received 7 August 1995. et al., 1984; Ellis et al., 1986), the presence of truncated MHC class I antigen on trophoblast cells (Ellis et al., 1990), and local production of immunoregulatory factors, such as the ovine trophoblast protein-1 (OTP-1) (Newton et al., 1989; Niwano et al., 1989; Fillion et al., 1991). A local rather than a systemic immunosuppression has been demonstrated (Chaouat and Monnot, 1984; Pandian et al., 1988; Lambert et al., 1989a). Suppressive activity affects the functional activities of NK cells (Kolb et al., 1984), cytotoxic cells (Chaouat and Kolb, 1985) and macrophages (Lu et al., 1984). The inhibition of the proliferative response to lectins, such as phytohaemagglutinin (PHA) and concanavalin $\mathrm{A}$, by soluble immunosuppressive factors obtained from embryo culture supernatant has also been documented (Kolb et al., 1984; Chaouat and Kolb, 1985; Daya and Clark, 1986a,b; Watson, 1990).

Although action of immunosuppressants specific for gestation has been described in detail, their mechanisms of action remain elusive. Blastocoelic fluid is known to have an immunosuppressive activity (Pandian et al., 1988) that is modulated during rabbit embryonic development with peak activity on days 12-13 (Lambert et al., 1989a). We demonstrate that this fluid, taken at day 12 of rabbit embryonic development, exerts an antiproliferative effect on lymphocytes by inhibiting interleukin 2 (IL-2) and interleukin 2 receptor (IL-2R) expression at the mRNA and protein levels.

\section{Materials and Methods}

Animals

Mature New Zealand white rabbits weighing $3.0-3.5 \mathrm{~kg}$ were housed separately and given free access to food and 
water. The does in oestrus were identified by the presence of oedematous and purple vulvae and chosen for the experiments. The day of oestrus was counted as day 0 . On that day, the does were mated and then injected i.v. with 75 iu human chorionic gonadotrophin (hCG, APL; Ayerst Laboratories, Montréal) to ensure ovulation.

\section{Collection of rabbit blastocoelic fluid}

The procedure for collecting blastocoelic fluid is as described by Lambert et al. (1989b). Briefly, at day 12 of pregnancy, the rabbits were killed by an overdose of Euthanyl (MTC Pharmaceutique Ltd, Cambridge, Ontario) and the uteri were removed. Blastocoelic fluid from rabbits at day 12 of pregnancy was then aspirated by a syringe from the cavities of the embryos and centrifuged ( $1650 \mathrm{~g}$ for $10 \mathrm{~min}$ ). Supernatants from day-12 blastocoelic fluid from the same female were pooled and kept frozen at $-20^{\circ} \mathrm{C}$ until use.

\section{Preparation of lymphocytes}

Rabbit blastocoelic fluid taken at day 12 of embryonic development is known to prevent $\left[{ }^{3} \mathrm{H}\right]$ thymidine uptake by heterologous (human) or autologous lymphocytes (Pandian et al., 1988; Lambert et al., 1989a). Because the effect of day-12 blastocoelic fluid was the same in heterologous conditions (rabbit day-12 blastocoelic fluid versus human lymphocytes) as in autologous conditions (day-12 blastocoelic fluid and lymphocytes from the same rabbit) and because human blood is easier to obtain, all experiments described here were conducted on human lymphocytes.

Blood from healthy volunteers was collected in sterile tubes containing heparin and diluted two-fold with sterile Hank's balanced salt solution (HBSS) in $50 \mathrm{ml}$ conical tubes (Falcon Beckton-Dickinson, Lincoln Park, NJ). Peripheral blood lymphocytes were prepared using Histopaque 1077 (Sigma, Mississauga, Ontario) density gradient. Histopaque $(10 \mathrm{ml})$ was added to the bottom of the tube with a sterile Pasteur pipette. The tube was then centrifuged at $800 \mathrm{~g}$ for $20 \mathrm{~min}$ at room temperature. The peripheral blood lymphocytes collected at the interface were washed twice with HBSS and were then resuspended $\left(2 \times 10^{6}\right.$ cells ml $\left.^{-1}\right)$ in RPMI 1640 containing glutamine, streptomycin (100 $\mathrm{mg} \mathrm{ml}^{-1}$ ), and penicillin (100 iu $\mathrm{ml}^{-1}$ ) (all from Flow Laboratories, Montréal), and 10\% fetal bovine serum (FBS).

\section{Cell cultures}

The cells $\left(2 \times 10^{5}\right.$ in $100 \mu$ l of cell suspension) were placed in a 96-well flat-bottomed microtitre plate (Falcon) with $25 \mu \mathrm{l}$ of concanavalin A ( $5 \mu \mathrm{g} \mathrm{ml}^{-1}$ final concentration), $50 \mu \mathrm{l}$ day- 12 blastocoelic fluid or RPMI 1640 (negative control) and $50 \mu \mathrm{l}$ RPMI 1640 containing FBS. The final concentration of FBS was $6.7 \%(\mathrm{v} / \mathrm{v})$. The plates were incubated at $37^{\circ} \mathrm{C}$ under a humidified atmosphere and $5 \% \mathrm{CO}_{2}$ for $48 \mathrm{~h}$. Ten microlitres of $0.02 \mathrm{mCi}\left[^{3} \mathrm{H}\right]$ thymidine $\mathrm{ml}^{-1}\left(2.0 \mathrm{Ci} \mathrm{mmol} \mathrm{1^{-1 }}\right.$; New England Nuclear, Lachine, Québec) was then added, and the incubation was continued for a further 18-24 h. The cells were harvested on glass fibre filters (Wallac, Turku, Finland) with a multiple cell harvester (Skatron, Lier, Norway), and the filter discs corresponding to each well were placed into a scintillation vial with $3 \mathrm{ml}$ Formula 963 (aqueous scintillation cocktail; Dupont, New England Nuclear, Lachine, Quebec). The incorporated radioactivity was then evaluated by liquid scintillation counter and calculated as described by Pandian et al. (1988) and Lambert et al. (1989a). For northern blot analysis and IL-2 assays, the cells were cultured in 24-well culture plates ( $900 \mu \mathrm{l}$ per well; $400 \mu \mathrm{l}$ cell suspension, $100 \mu \mathrm{l}$ concanavalin A, $200 \mu \mathrm{l}$ day-12 blastocoelic fluid or RPMI, and $200 \mu \mathrm{l}$ RPMI containing FBS to a final FBS concentration of $6.7 \%$ ) and treated as described above.

The cells used in the prestimulation studies were cultured in 24-well flat-bottomed culture plates $\left(8 \times 10^{5}\right.$ cells in a total volume of $900 \mu \mathrm{l}$ ) with $5 \mu \mathrm{g}$ concanavalin $\mathrm{A} \mathrm{ml}^{-1}$. After incubating $\left(37^{\circ} \mathrm{C}, 5 \% \mathrm{CO}_{2}\right)$ for $72 \mathrm{~h}$, the cells were harvested, washed twice in RPMI, and subcultured in 96-well flatbottomed culture plates as described above, either with or without concanavalin A and day-12 blastocoelic fluid or RPMI. $\left[^{3} \mathrm{H}\right.$ ]thymidine $\left(10 \mu \mathrm{l}\right.$ of a $0.02 \mathrm{mCi} \mathrm{ml}^{-1}$ solution) was added $18 \mathrm{~h}$ before counting by liquid scintillation.

\section{Flow cytometry studies}

Analysis of DNA content. Treated lymphocytes from 96-well culture plates were transferred into $1.5 \mathrm{ml}$ polypropylene tubes and centrifuged at $600 \mathrm{~g}$ for $5 \mathrm{~min}$, washed with PBS $(\mathrm{pH} 7.2)$ and then fixed in PBS $-70 \%(\mathrm{v} / \mathrm{v})$ ethanol. Fixed cells were kept at $-20^{\circ} \mathrm{C}$. Before analysis, the cells were centrifuged $(600 \mathrm{~g}$ for $2 \mathrm{~min}$ ), washed with PBS, and incubated for $30 \mathrm{~min}$ at $37^{\circ} \mathrm{C}$ in PBS containing RNase $\left(40 \mathrm{U} \mathrm{ml}^{-1}\right.$ per $10^{\circ}$ cells) (Boehringer-Mannheim, Mannheim). The cells were centrifuged $(600 \mathrm{~g}$ for $5 \mathrm{~min})$ and resuspended in $500 \mu \mathrm{l} \mathrm{PBS}$ containing the DNA dye, propidium iodide $\left(50 \mu \mathrm{g} \mathrm{ml}^{-1}\right)$ (Sigma), and incubated on ice for $30 \mathrm{~min}$. Analysis of DNA content was performed using a Coulter Epics 753 pulse cytometer (Coulter, Hialeah, FL). The cells were excited at $488 \mathrm{~nm}(400 \mathrm{~mW})$ and red fluorescence, measuring total DNA, was recorded over $590 \mathrm{~nm}$. The percentages of cells in $\mathrm{Go} / \mathrm{G} 1, \mathrm{~S}$ and $\mathrm{G} 2 / \mathrm{M}$ phases were calculated from the resulting DNA content histograms using the PARAI program (Coulter). Debris and doublets were eliminated by plotting integrated red fluorescence and by setting a bitmap around the events on the diagonal (Go/G1, S and G2M singlets) (Dressler and Bartow, 1989). Chicken red blood cells (2.5 pg DNA per diploid nucleus), trout red blood cells (5.5 pg DNA per diploid nucleus) and human white blood cells (7.0 pg DNA per diploid nucleus) were used as reference standards (Tiersh et al., 1989).

IL-2R membrane expression studies. Lymphocytes harvested from 96-well culture plates were washed twice and resuspended in $300 \mu \mathrm{l} \mathrm{PBS}$ (pH 7.4) before being incubated with $5 \mu \mathrm{l}$ fluorescein isothiocyanate (FITC)-conjugated mouse (IgGIa) antihuman IL-2R $\alpha\left(4^{\circ} \mathrm{C}, 15 \mathrm{~min}\right)$ antibody (Coulter) or FITCconjugated mouse $\mathrm{IgGla}$ (isotypic control). Fluorescence was analysed by flow cytometry (Coulter Epics $\mathrm{C}$ cell sorter system). 


\section{Northern blot analysis}

The lymphocytes were recovered from the 24-well tissue culture plates, pooled, and pelleted by centrifugation $(800 \mathrm{~g}$ for $15 \mathrm{~min}$ ) in $50 \mathrm{ml}$ polypropylene tubes (Falcon). Total RNA was extracted using the method of Chomczynski and Sacchi (1987) and the samples were subsequently analysed by blot hybridization using Hybond-N (Amersham, Oakville, Ontario) as transfer membrane. cDNAs encoding human IL-2 (obtained from American Tissue Culture Collection ATTC: no. 67618), human IL-2R $\alpha$ (generously provided by W. C. Greene, Gladstone Institute, San Francisco, CA), or human GAPDH were digested with the appropriate restriction enzymes and the purified inserts were labelled with the Quick Prime kit (Pharmacia, Baie d'Urfe, Quebec) according to the manufacturer's procedure with $a^{32} \mathrm{P}$ dCTP $\left(3000 \mathrm{Ci} \mathrm{mmol} \mathrm{l}^{-1}\right.$, Amersham). The probes were purified as described by Chapdelaine et al. (1990).

\section{IL-2 assays}

Supernatants of treated or control cells (cultured in 24-well tissue culture plates) were taken at various times and kept at $-20^{\circ} \mathrm{C}$ until use. Interleukin 2 was assayed with an ELISA kit detecting the human cytokine (Cayman Chemical Company, Ann Harbor, MI) according to the manufacturer's guidelines.

\section{Treatment with cytokines}

Human recombinant IL-1 $\alpha$, IL-4, IL-6, and tumour necrosis factor $\alpha$ (TNF- $\alpha$ ) were purchased from R\&D systems and IL-2 $\left(2 \times 10^{6} \mathrm{U} \mathrm{mg}^{-1}\right)$ from Boehringer-Mannheim. Prestimulated cells were washed twice in RPMI and resuspended in

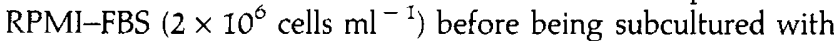
concanavalin $\mathrm{A}$ alone or in combination with day- 12 blastocoelic fluid. Recombinant cytokines were immediately added, and the incubation was continued for $24 \mathrm{~h}$. Six hours after the beginning of the subculture, the cells were labelled with $\left[{ }^{3}\right.$ H]thymidine as described. All the cytokines were tested simultaneously in the same assay using the same medium and the same peripheral blood lymphoctyes for every cytokine.

\section{Statistical analysis}

Statistical treatments were performed using Duncan-Kramer multiple comparison tests or paired-sample $t$ test, as indicated.

\section{Results}

\section{Antiproliferative effect of day-12 blastocoelic fluid on human} peripheral blood lymphocytes

Table I presents the results obtained by culturing human peripheral blood lymphocytes with concanavalin $\mathrm{A}$, concanavalin A plus day-12 blastocoelic fluid, or culture medium alone (nonstimulated cells) and demonstrates the strong inhibitory effect of day-12 blastocoelic fluid (95\%) on the concanavalin A-dependent T-cell proliferation. This inhibition was further characterized by undertaking cell cycle studies by flow cyto-
Table 1. Immunosuppressive properties of rabbit blastocoelic fluid collected on day 12 of pregnancy

\begin{tabular}{|c|c|c|}
\hline Treatment $^{a}$ & $\begin{array}{l}{\left[{ }^{3} \mathrm{H}\right] \text { thymidine }} \\
\text { incorporation }{ }^{6} \\
\text { (c.p.m.) }\end{array}$ & $\begin{array}{c}\text { Inhibition }^{\text {bc }} \\
(\%)\end{array}$ \\
\hline $\begin{array}{l}\text { Concanavalin A (ConA) } \\
\text { ConA + day-12 blastocoelic fluid } \\
\text { Nonstimulated cells }\end{array}$ & $\begin{array}{l}19989 \pm 1297 \\
1023 \pm 395 \\
1195 \pm 558\end{array}$ & $\begin{array}{c}- \\
95 \pm 1 \\
-\end{array}$ \\
\hline $\begin{array}{l}\text { "concanavalin } A \text { and concanavalin } \\
\text { nonstimulated cells: } n=14 . \\
\text { b'Means } \pm \text { sEM. } \\
\text { c } \% \text { inhibition }=\frac{\text { c.p.m. Con } A-\text { c.p.m. }}{}\end{array}$ & $\begin{array}{l}\text { day-12 blastocoe } \\
+ \text { day-12 blastoc }\end{array}$ & $\begin{array}{l}\text { fluid: } n=32 \text {; } \\
\text { lic fluid } \\
\qquad 100 .\end{array}$ \\
\hline
\end{tabular}

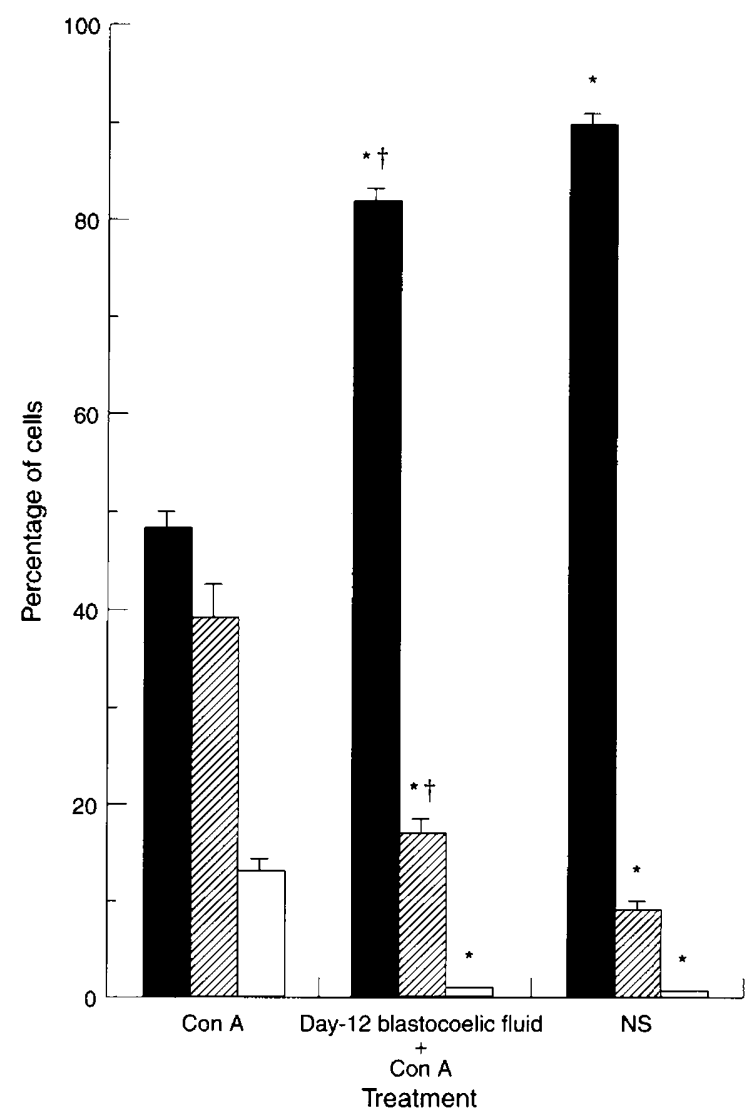

Fig. 1. Cell-cycle analysis of lymphocytes treated with day-12 blastocoelic fluid. Cells were evaluated for their DNA content after incubation for $72 \mathrm{~h}$ in 96 -well culture plates. The percentage of cells in Go/G1 ( $\square), S(\varpi)$, and G2/M ( $\square$ ) is shown. Each histogram represents the mean \pm SEM of four experiments performed in triplicate. ${ }^{*} P<0.01$, significantly different from concanavalin $\mathrm{A}(\mathrm{Con} \mathrm{A})$ values. ${ }^{\dagger} P<0.01$, significantly different from nonstimulated (NS) values as determined by Duncan-Kramer multiple comparison test.

metric analysis of DNA content in concanavalin A-stimulated cells treated with day 12 blastocoelic fluid, concanavalin A-stimulated and nonstimulated cells. More than $80 \%$ of the concanavalin A/day-12 blastocoelic fluid-treated cells remained 
in the Go/GI phase (Fig. 1), suggesting that the addition of day-12 blastocoelic fluid to the culture maintains the lymphocytes in a quiescent state, despite the continuous presence of concanavalin A throughout the $72 \mathrm{~h}$ treatment. A significant inhibition of cell cycle progression $(P<0.01)$ is also reflected in the $S$ and $G 2 / M$ phases, where only $16.7 \pm 0.7 \%$ and $0.8 \pm 0.2 \%$ of the cell population, respectively, were propidium iodide-labelled in the concanavalin A/day- 12 blastocoelic fluidtreated cells in contrast to $38.9 \pm 2.5 \%$ and $13.0 \pm 1.0 \%$, respectively, for concanavalin A-stimulated cells. However, despite the strong inhibitory effect, concanavalin A/day-12

(a)

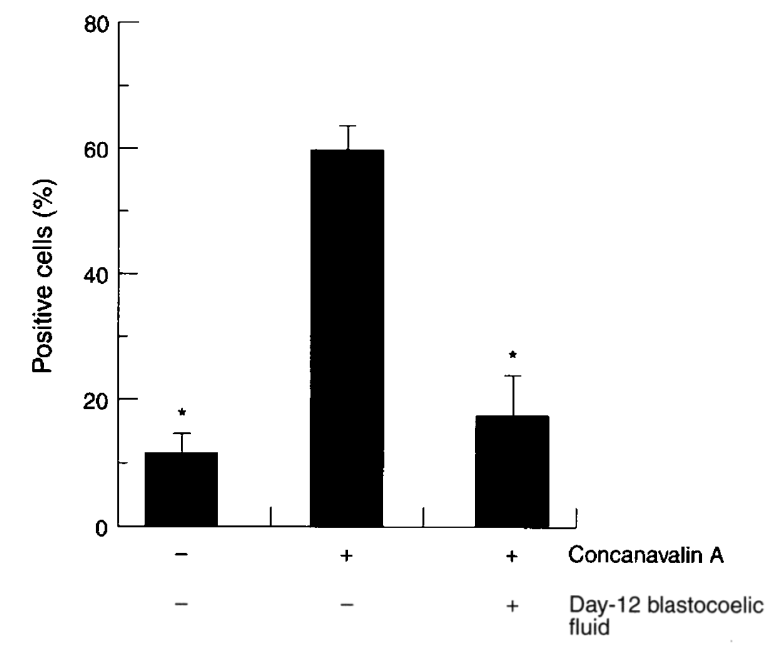

(b)

285
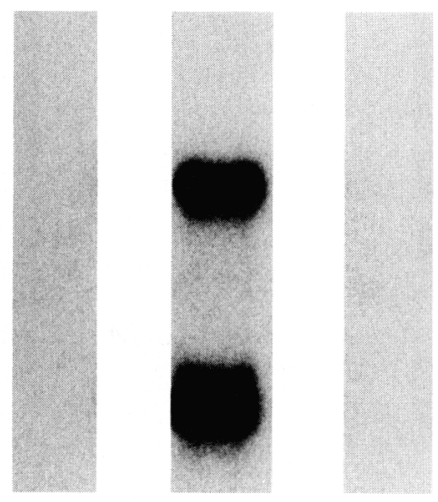

$-\mathrm{IL}-2 \mathrm{R}$

(c)

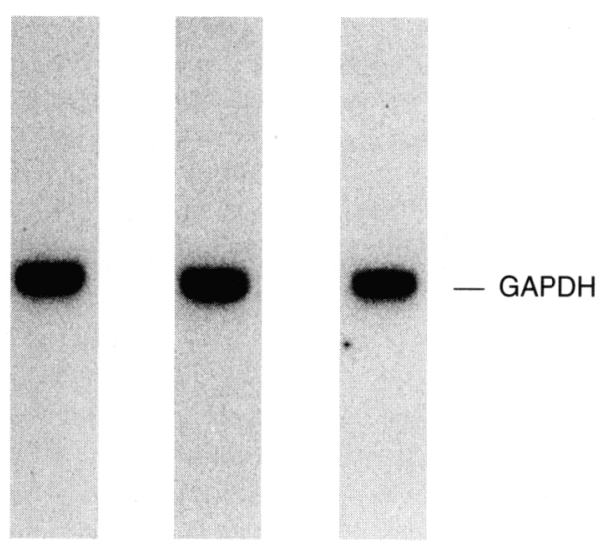

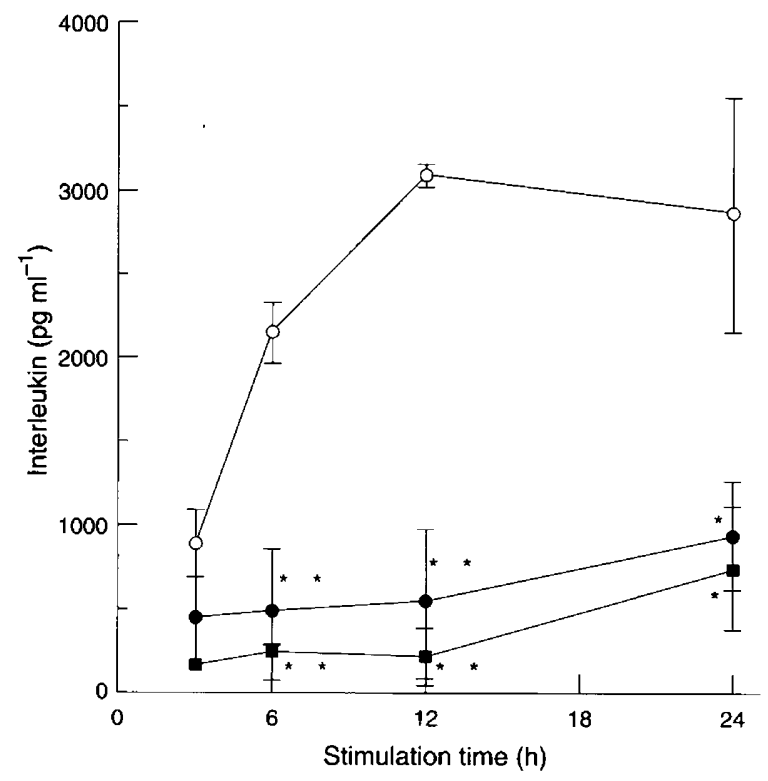

Fig. 3. Interleukin 2 secretion by cells treated with $(O)$ concanavalin $A$; (-) concanavalin A+ day-12 blastocoelic fluid; or ( $)$ without concanavalin $A$. Culture supernatants collected at various times were diluted 1:50 with RPMI-1640, frozen at $-20^{\circ} \mathrm{C}$ and assayed for secreted interleukin 2. Each point represents the mean \pm SEM of three experiments performed in duplicate. A total of eight different day-12 blastocoelic fluid samples were tested on the lymphocytes of three donors. ${ }^{*} P<0.05 ;{ }^{* *} P<0.01$, significantly different from concanavalin $A$ values as determined by Duncan-Kramer multiple comparison test.

blastocoelic fluid-treated cells progressed significantly in the cell cycle compared with nonstimulated cells for the Go/G1 phase $(82.4 \pm 0.8 \%$ versus $90.1 \pm 0.9 \% ; P<0.01)$ and $S$ phase $(16.7 \pm 0.7 \%$ versus $8.5 \pm 1.3 \%$; $P<0.01)$. There was, however, no significant difference for the G2/M phase.

Day-12 blastocoelic fluid negatively affects IL-2 and IL-2R gene expression

It is known that IL-2R $\alpha$ appears at the cellular surface after T-cell activation (Leonard et al., 1985; Altman et al., 1990) and

Fig. 2. Expression of interleukin 2 (IL-2) receptor on day-12 blastocoelic fluid-treated cells. Peripheral blood lymphocytes were incubated for $72 \mathrm{~h}$ with and without concanavalin $\mathrm{A}$ and day-12. blastocoelic fluid in 24-well tissue culture plates. The cells were recovered and membrane expression of IL-2R $\alpha$ was determined by flow cytometry or northern blot analysis after extraction of RNA. (a) IL-2R membrane expression was evaluated by direct fluorescence with an anti-IL-2 receptor antibody labelled with fluorescein isothiocyanate. Nonspecific fluorescence was assessed by the use of an isotypic mouse immunoglobulin labelled with the same fluorochrome. The percentage of positive cells for IL-2R membrane expression is shown as percentage fluorescence. Each histogram represents the mean \pm SEM of three experiments performed in duplicate. ${ }^{*} P<0.001$, significantly different from concanavalin $A$ values, as determined by Duncan-Kramer multiple comparison test. (b, c) Total mRNA (10 $\mu \mathrm{g}$ per lane) was hybridized with ${ }^{32} \mathrm{P}$-labelled IL-2R or GAPDH probes and exposed at $-80^{\circ} \mathrm{C}$ for $24 \mathrm{~h}(\mathrm{GAPDH})$ or $96 \mathrm{~h}$ (IL-2R). 
(a)

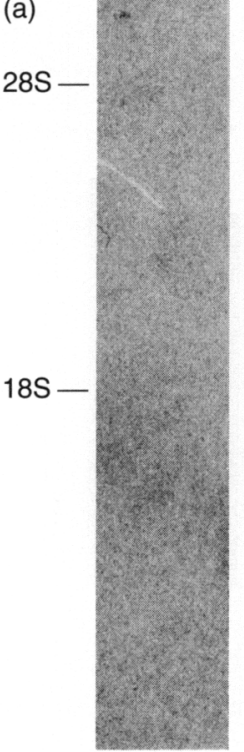

$-$

$-$

(b)

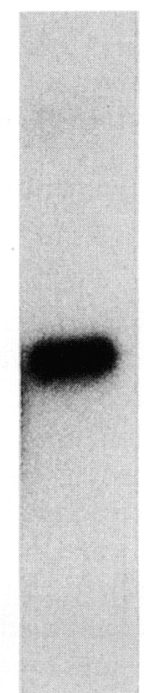

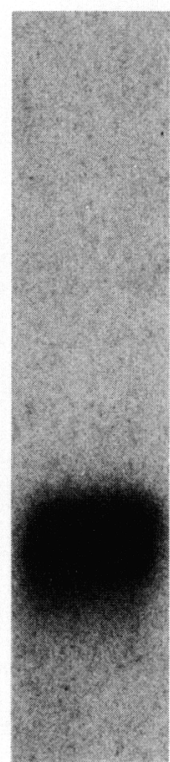

$+$
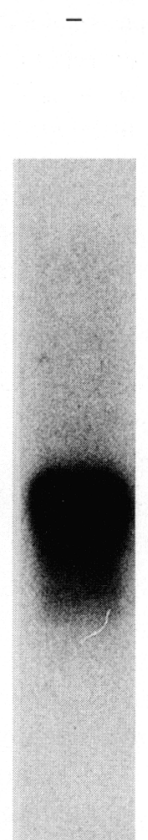

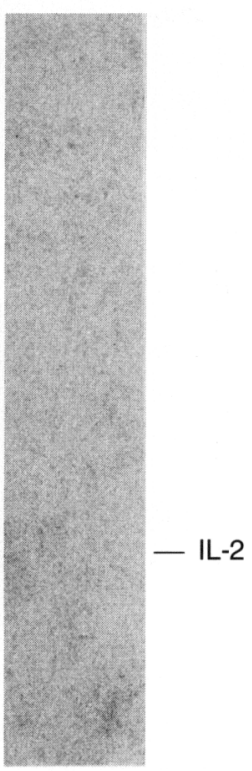

+ Concanavalin A

+ Day-12 blastocoelic fluid

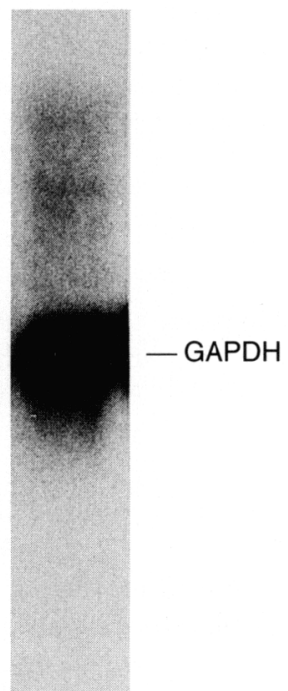

Fig. 4. mRNA expressing interleukin 2 (IL-2) in cells treated with day-12 blastocoelic fluid. Peripheral blood lymphocytes were incubated for $72 \mathrm{~h}$ with and without concanavalin $\mathrm{A}$ and day- 12 blastocoelic fluid in 24-well tissue culture plates. The cells were recovered; RNA was extracted; and northern blot analysis was performed. Total mRNA (10 $\mu \mathrm{g}$ per lane) was hybridized with ${ }^{32} \mathrm{P}$-labelled interleukin $2 \mathrm{R}$ (a) or GAPDH (b) probes and exposed at $-80^{\circ} \mathrm{C}$ for $24 \mathrm{~h}$ (GAPDH) or $96 \mathrm{~h}$ (interleukin 2).

that interaction between IL-2 and its receptor is necessary for the progression of activated T-cells through the cell cycle and their subsequent proliferation (Cantrell and Smith, 1984). Day-12 blastocoelic fluid treatment prevents IL-2R $\alpha$ membrane expression on lymphocytes (Fig. 2a), which may reflect the quiescent state of concanavalin A/day-12 blastocoelic fluid- treated cells observed in Fig. 1. As there was no cellular IL-2R $\alpha$, no cell-cycle progression, and no proliferation in concanavalin A/day-12 blastocoelic fluid-treated cells compared with concanavalin A cells, an attempt was made to determine whether IL-2R $\alpha$ gene expression, normally induced by concanavalin A, was maintained quiescent by day-12 blastocoelic fluid treatment. As expected, no IL-2R $\alpha$ mRNA could be detected in concanavalin A/day-12 blastocoelic fluid-treated cells as determined by northern blot analysis (Fig. 2b). The double hybridization is due to some alternative splicing, and the lower band represents a transcript lacking 216 bases and is not involved in the production of an active protein (Leonard et al., 1984). Because the expression of IL-2R $\alpha$ is known to be regulated by IL-2 (Reem and Yeh, 1984; Welte et al., 1984), the low IL-2R $\alpha$ expression was correlated with IL-2 gene expression by measuring IL-2 production of concanavalin A/day-12 blastocoelic fluid-treated lymphocytes. Production of IL-2 was significantly inhibited $(P<0.01)$ by day-12 blastocoelic fluid (Fig. 3).

The results confirmed that day-12 blastocoelic fluid prevents IL-2 gene expression (Fig. 4) and suggest a rapid inhibitory effect of day-12 blastocoelic fluid taking place before $6 \mathrm{~h}$, as shown by IL-2 secretion (Fig. 3). This is also the minimal time required to detect mRNA encoding IL-2 in concanavalin A-stimulated cells (D. Bergeron, M. Audette and R. D. Lambert, unpublished).

\section{Exogenous IL-2 and prevention of inhibition by day-12} blastocoelic fluid

The lymphocytes were prestimulated with concanavalin A alone for $72 \mathrm{~h}$ to determine whether the presence of IL-2 could neutralize the day-12 blastocoelic fluid-mediated inhibition. This experimental condition was based on the demonstration (Cantrell and Smith, 1984) that lymphocyte proliferation peaks when a maximum of cell surface IL-2R expression is attained, which is $72 \mathrm{~h}$ after lectin activation (Leonard $e t$ al., 1985; Smith, 1988). This prestimulation induces a high membrane expression of IL-2R ( $68 \pm 13 \%$; D. Bergeron, M. Audette and R. D. Lambert, unpublished). Although it strongly inhibits $\left[{ }^{3} \mathrm{H}\right]$ thymidine incorporation (Fig. 5a), day-12 blastocoelic fluid did not completely abolish cell proliferation (Fig. $5 \mathrm{~b}$ ) and failed to decrease IL-2R membrane expression ( $64 \pm 4 \%$; D. Bergeron, M. Audette and R. D. Lambert, unpublished). Therefore, day-12 blastocoelic fluid does not exert its inhibitory activities by downregulating IL-2R expression.

The next aim was to determine whether day-12 blastocoelic fluid interfered with proliferative transduction signals emanating from IL-2R after interaction with IL-2. The inhibitory activity of day- 12 blastocoelic fluid was totally prevented by the addition of $20 \mathrm{U}$ human recombinant IL-2 $\mathrm{ml}^{-1}$ (Fig. 6), indicating that its receptor was still functional despite the presence of day-12 blastocoelic fluid. Interleukin 1a, IL-4, IL-6 and TNF- $\alpha$ are also known to play a role in lymphocyte proliferation (Durum et al., 1985; Paul and Ohara, 1987; Lotz et al., 1988). None of these cytokines could totally prevent the inhibitory effect of day-12 blastocoelic fluid in the range of concentrations used (Fig. 7). 

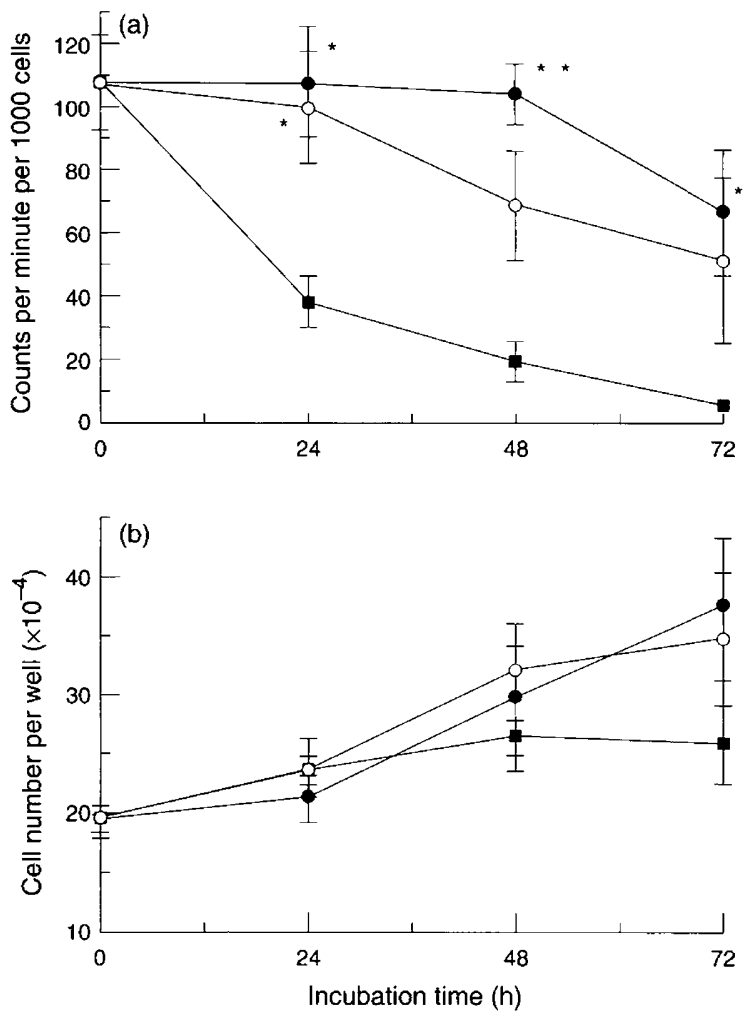

Fig. 5. Proliferation profile of concanavalin A day-12 blastocoelic fluid-treated prestimulated cells as a function of time. The cells were prestimulated with concanavalin A for $72 \mathrm{~h}$ in 24-well culture plates before they were recultured (96-well culture plates) with (-) concanavalin $A_{;}(\boldsymbol{\square})$ concanavalin $A+$ day-12 blastocoelic fluid; or $(O)$ without concanavalin A. (a) The c.p.m. per 1000 cells was calculated from data shown in (b) and total $\left[{ }^{3} \mathrm{H}\right]$ thymidine incorporation (not shown). (b) Number of cells (haemocytometer) per well. Each histogram represents the mean \pm SEM of six experiments performed in triplicate. $* P<0.05 ; * * P<0.01$, significantly different from concanavalin $\mathrm{A}+$ day-12 blastocoelic fluid values.

\section{Discussion}

The strong inhibitory effect of day-12 blastocoelic fluid cannot be attributed to cytotoxicity because, as stated by Pandian $e$ al . (1988), lymphocytes treated with day-12 blastocoelic fluid showed a viability higher than $90 \%$ and pretreatment of lymphocytes with day-12 blastocoelic fluid for $24 \mathrm{~h}$ does not alter their ability to proliferate in response to concanavalin $\mathrm{A}$ when the blastocoelic fluid is removed (Pandian et al., 1988). In addition, in the present study it was demonstrated that preactivated (IL-2R positive) lymphocytes responded to IL-2, despite the presence of day-12 blastocoelic fluid. The results are not due to a cytotoxic combination of FBS with day-12 blastocoelic fluid, as a strong inhibition of $\left[{ }^{3} \mathrm{H}\right]$ thymidine incorporation is still observed in a chemically defined serumfree medium (D. Bergeron, M. Audette and R. D. Lambert, unpublished).

In this study, we demonstrated that day-12 blastocoelic fluid prevented lymphocytes from undergoing cell cycling. The differences observed in the proportions of concanavalin A/day-12 blastocoelic fluid cells in Go/G1 and S phases

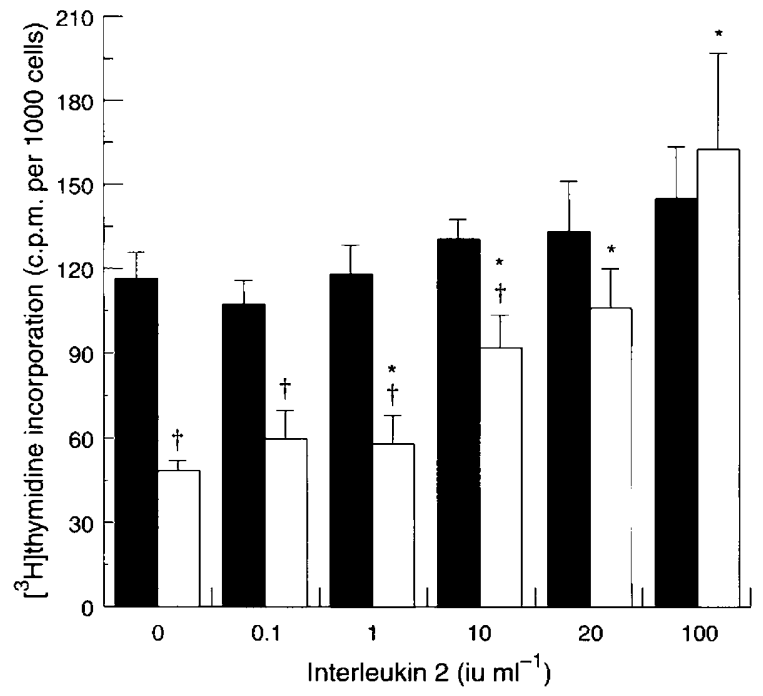

Fig. 6. Exogenous interleukin 2 (IL-2) can prevent day-12 blastocoelic fluid-mediated inhibition. $\left[{ }^{3} \mathrm{H}\right]$ thymidine incorporation was measured on prestimulated lymphocytes in the presence or absence of IL-2 (control). Various concentrations of human recombinant IL-2 were added simultaneously with concanavalin $A(\boldsymbol{\square})$ or with concanavalin $A+$ day-12 blastocoelic fluid ( $\square$ ) to cells prestimulated for $72 \mathrm{~h}$. The incubation was continued for an additional $24 \mathrm{~h}$ and incorporated radioactivity was measured. The c.p.m. per 1000 cells were calculated from data shown in Fig. 5(b). Each histogram represents the mean \pm SEM of three to four experiments performed in triplicate. ${ }^{*} P<0.05$, significantly different from concanavalin $\mathrm{A}+$ day- 12 blastocoelic fluid values at no cytokine addition. ${ }^{\dagger} P<0.05$, significantly different from concanavalin $A$ values at the same cytokine concentration.

compared with nonstimulated cells are probably due to the fact that some of the cellular events that occur after concanavalin A interaction with the cell surface occur before day-12 blastocoelic fluid-mediated inhibition takes place, which suggests that cells treated with day-12 blastocoelic fluid are stopped in their transition from Go/G1 into $S$ phase. Because IL-2 interaction with IL-2R $\alpha \beta$ (high affinity IL-2R) is necessary for such a transition to occur (Cantrell and Smith, 1984), we postulate that day-12 blastocoelic fluid hinders the proliferation of treated lymphocytes by preventing the appearance of mRNA encoding IL-2R $\alpha$, and therefore its membrane expression, indirectly by inhibiting IL-2 secretion/ gene expression. All the results confirm the validity of this hypothesis.

The observation that IL-2 can reverse the inhibitory effect of day-I2 blastocoelic fluid when IL-2R are present on the cell surface of leukocytes also supports this interpretation. However, IL-2 present in the incubation medium after a prestimulation for 12 or $24 \mathrm{~h}$ fails to reverse the inhibitory effect of day-12 blastocoelic fluid (D. Bergeron, M. Audette and R. D. Lambert, unpublished). Given that membrane IL-2R $\alpha$ expression is not initiated until $15 \mathrm{~h}$ of lectin stimulation (Leonard et al., 1985), closely paraliels $\left[{ }^{3} \mathrm{H}\right]$ thymidine uptake (Cantrell and Smith, 1984), and peaks at $72 \mathrm{~h}$ after lectin activation (Leonard et al., 1985; Smith, 1988), we suggest that day-12 blastocoelic fluid may be acting on IL-2R $\alpha$ gene expression or IL-2Ra membrane expression, independently 


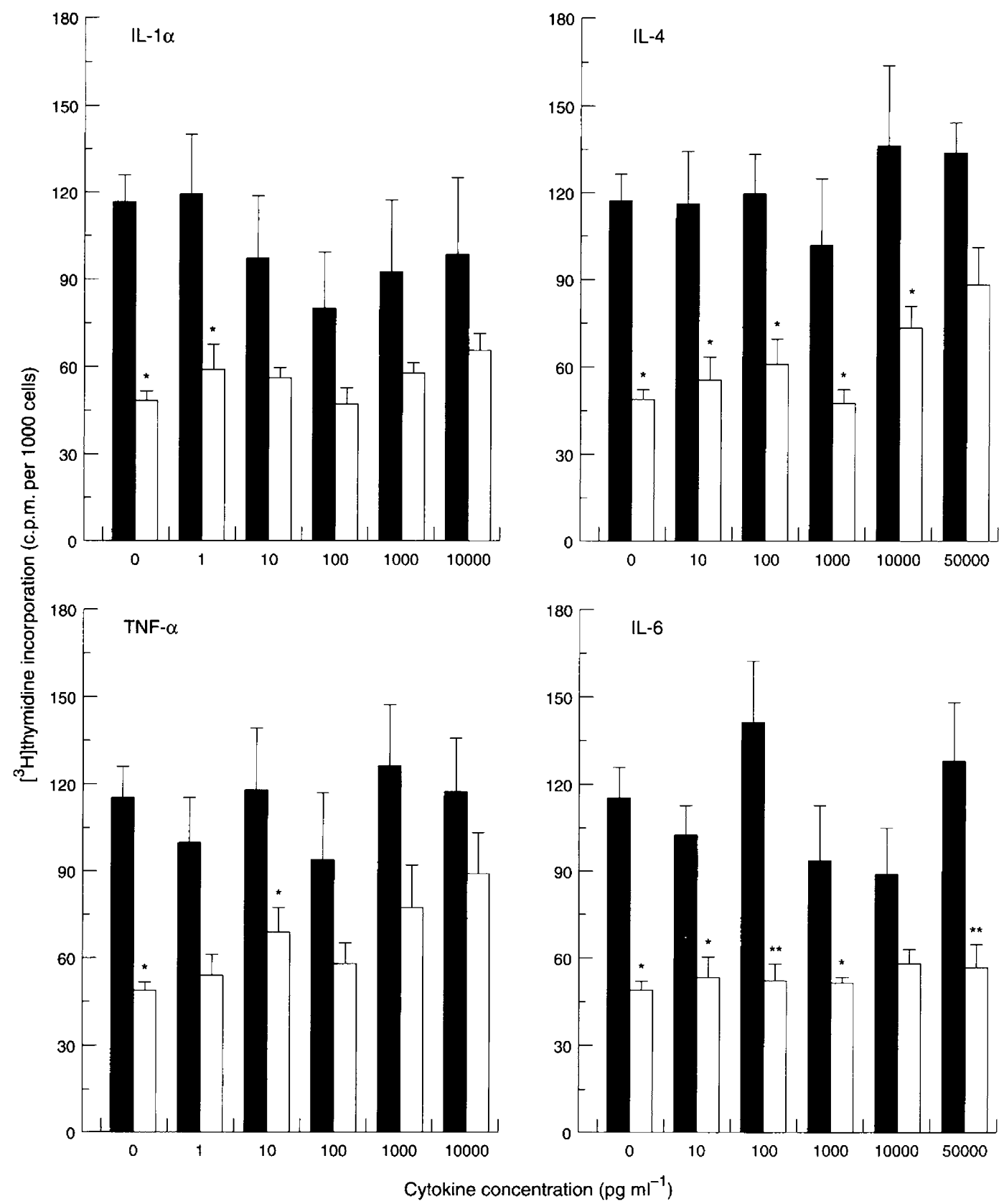

Fig. 7. Exogenous interleukin I $\alpha$ (IL-I $\alpha$ ) IL-4, IL-6, or tumour necrosis factor $\alpha$ (TNF- $\alpha$ ) cannot prevent day-12 blastocoelic fluid-mediated inhibition. $\left[{ }^{3} \mathrm{H}\right]$ thymidine incorporation was measured on the same prestimulated lymphocytes as those used in Fig. 6 in the presence or absence of cytokine (control). Various concentrations of cytokines were added simultaneously with ( $\square$ ), concanavalin $A$ or $(\square)$, concanavalin $A+$ day-12 blastocoelic fluid. The incubation was continued for an additional $24 \mathrm{~h}$ and incorporated radioactivity was measured. The c.p.m. per 1000 cells was calculated from data shown in Fig. 5b. Each histogram represents the mean \pm SEM of three to four experiments done in triplicate. ${ }^{*} P<0.05 ;{ }^{*} P<0.01$, significantly different from concanavalin $\mathrm{A}$ values at the same cytokine concentration.

from IL-2 gene transcription. The fact that day-12 blastocoelic fluid does not prevent expression of the gene encoding GAPDH indicates that a day-12 blastocoelic fluid suppressive effect is not due to a nonspecific inhibition of the transcription machinery, and is another indication that this suppression is not the result of a cytotoxic effect.
Interleukin 2 can be a mediator of pregnancy failure; indeed, in early pregnancy, NK-like cells are present in relatively large quantities in the decidua (Croy et al., 1985; Gambel et al., 1985) and seem to be implicated in spontaneous abortions (de Fougerolles and Baines, 1987; Gendron and Baines, 1988). Granulated metrial gland cells, found in rodents (Croy, 1990), 
and large granulated lymphocytes, found in humans (King and Loke, 1991), are present in early decidua, both of which are related morphologically, phenotypically and functionally to NK cells (Croy, 1990; King and Loke, 1990; Lin et al., 1991). Although several studies establish that naive NK cells cannot kill trophoblastic cells in vitro (Croy et al., 1985; Drake and Head, 1989; King et al., 1992), King and Loke (1990) observed that IL-2 converts decidual large granulated lymphocytes into more classic NK cells and that such a treatment greatly increases the large granulated lymphocyte lytic activity, including killing normal and malignant trophoblastic cells. It is not known whether lymphokine activated killer (LAK) cell generation occurs in vivo, but Lala et al. (1990) showed that activation of mouse maternal NK cells with IL-2 or indomethacin administration, which reduces $\mathrm{PGE}_{2}$ production and therefore promotes IL-2 synthesis, greatly increases the abortion rate of treated animals.

We propose that day-12 blastocoelic fluid serves as a potent regulator of cell proliferation/function in quiescent as well as activated immune cells in vivo, before the arrival of maternal suppressor cells in the implantation region (Lambert et al, 1989a). In addition, because inhibition of prestimulated cells mediated by day-12 blastocoelic fluid is reversible (D. Bergeron, M. Audette and R. D. Lambert, unpublished), this effect could be considered a transient inhibitor regulating the functions and proliferation of potentially harmful activated maternal lymphocytes coming in close contact with the placenta and the fetus via the blood circulation. Although the mechanism of action of day- 12 blastocoelic fluid on prestimulated lymphocytes is unknown, it could affect an IL-2independent proliferation pathway, as no IL-2 could be detected in the supernatant of prestimulated lymphocytes even during the first $48 \mathrm{~h}$ after subculture where proliferation occurs (D. Bergeron, M. Audette and R. D. Lambert, unpublished). Because IL-2-independent proliferation involves activation of protein kinase C (Takeshita et al., 1988), we hypothesize that inhibition by day-12 blastocoelic fluid inhibition occurs at or downstream from this kinase.

Day-12 blastocoelic fluid is not the only inhibitor of IL-2/IL-2R production. It has been demonstrated that rat amniotic fluid (Yoshimura et al., 1991) and pregnancy zone protein (Saito et al., 1990) inhibit IL-2 production without interfering with IL-2R membrane expression. Nicholas and Payani (1985) showed that retroplacental serum suppresses mixed lymphocyte reaction through an inhibition of IL-2 production. Yoshida et al. (1990) also found that this same type of serum can cause a reduction in IL-2R membrane expression on treated lymphocytes. As in the present study involving day-12 blastocoelic fluid, this inhibitory effect can be reversed by the addition of exogenous IL-2. Skibin et al. (1989) reported the inhibitory effects of a human factor released from the placental chorionic membrane that prevents the expression of IL-2R. In addition, hydatidiform mole extracts are known to suppress IL-2-induced proliferation of T-cells (Bennett et al., 1990).

The immunosuppressive properties of gestation-specific factors have been, in some cases, associated with their ability to bind IL-2 or IL-2R. Segerson and Libby (1990) provided experimental evidence that bovine uterine luminal protein suppresses lymphocyte proliferation by such a mechanism. Our results demonstrate that after treatment with day- 12 blastocoelic fluid, IL-2 and IL-2R proteins are not expressed, thus eliminating the participation of immunosuppressive IL-2 or IL-2R binding proteins as the causal event in the inhibitory effect. This conclusion is supported by the fact that the IL- $2 R$ present at the surface of prestimulated cells can bind IL-2 and transduce proliferative signals despite the presence of day- 12 blastocoelic fluid, ruling out the intervention of at least IL-2R binding proteins.

The physiological significance of the two-way day- 12 blastocoelic fluid-mediated inhibition of lymphocytes could be of great relevance. Because day-12 blastocoelic fluid-mediated immunosuppression is transient, that is, modulated during the course of embryo-fetal development (Lambert et al., 1989a), the active factor(s) could prevent placental transcription of the gene encoding IL-2 (and thus IL-2 secretion) before or during the migration of immunoregulatory cells to the decidua (Slapsys and Clark, 1982) which, at a certain stage in pregnancy, are thought to replace the protective role of embryo-fetal immunosuppressive factor(s) (Lambert et al., 1989a). We propose that the active molecule(s) present in day-12 blastocoelic fluid, which does not act by cytotoxic means as the effect is completely reversible (Pandian et al., 1988), could participate in the survival of the fetal semi-allograft by preventing transcription of genes encoding IL- 2 and IL-2R. Such a mechanism could thus prevent the accidental activation of lymphocytes located in the decidua that are potentially harmful to the fetus.

The authors thank R. Boulianne, P. Chapdelaine, and E. Gauthier for their very useful tips in plasmid preparation and northern blotting experiments; M. Belles-Isles and M. Dufour for help in cytometric determination of DNA content; and J. Kim and D. Castilaw for English editorial assistance. This work was supported by NSERC (R. D. Lambert), and a FRSQ scholarship (M. Audette).

\section{References}

Altman A, Coggeshall KM and Mustelin T (1990) Molecular events mediating T cell activation Advances in Immunology 48 227-361

Bennett WA, Brackin MN, McGehee RP and Cowan BD (1990) Hydatidiform mole pregnancy trophoblast extracts differentially suppress interleukin-2induced proliferation of human T-lymphocytes and PHA blasts American Journal of Reproductive Immunology 23 44-49

Cantrell DA and Smith KA (1984) The interleukin-2 T-cell system: a new cell growth model Science 224 1312-1316

Chaouat G and Kolb JP (1985) Immunoactive products of placenta. IV. Impairment by placental cells and their products of CTL. function at effector stage Journal of Immunology 135 215-222

Chaouat G and Monnot P (1984) Systemic active suppression is not necessary for successful allopregnancy American Journal of Reproductive Immunology 6 $5-8$

Chapdelaine P, Ho-Kim MA, Tremblay RR and Dubé JY (1990) Southern blot analysis with synthetic oligonucleotides. Application to prostatic protein genes International Journal of Biochemistry 22 75-82

Chomczynski P and Sacchi N (1987) Single-step method of RNA isolation by acid guanidium thiocyanate-phenol-chloroform extraction Analytical Biochemistry 162 156-159

Clark DA, Slapsys R, Croy BA, Krcek J and Rossant J (1984) Local active suppression by suppressor cells in the decidua: a review American Journal of Reproductive Immunology 5 78-83

Croy BA (1990) Granulated metrial cells. Interesting cells found in the pregnant uterus American Journal of Reproductive Immunology 23 19-21

Croy BA, Gambel P, Rossant J and Wegmann TG (1985) Characterization of murine decidual natural killer (NK) cells and their relevance to the success of pregnancy Cellular Immunology 93 315-326 
Daya S and Clark DA (1986a) Immunosuppressive factor (or factors) produced by human embryos in vitro New England Journal of Medicine 15 1551-1552

Daya S and Clark DA (1986b) Production of immunosuppressor factor(s) by preimplantation embryos American Journal of Reproductive Immunology and Microbiology $1198-101$

de Fougerolles AR and Baines MG (1987) Modulation of the natural killer cell activity in pregnant mice alters the spontaneous abortion rate Journal of Reproductive Immunology 11 147-153

Drake BL and Head JR (1989) Murine trophoblast can be killed by lymphokineactivated killer cells Journal of Immunology 143 9-14

Dressler LG and Bartow SA (1989) DNA flow cytometry in solid tumors: practical aspects and clinical applications Seminars in Diagnostic Pathology 6 $55-82$

Durum SK, Schmidt JA and Oppenheim JJ (1985) Interleukin I: an immunological perspective Annual Review of Immunology 3 263-287

Ellis SA, Sargent IL, Redman CW and McMichael AJ (1986) Evidences for a novel HLA antigen found on human extravillous trophoblast and a choriocarcinoma cell line Immunology 59 595-601

Ellis SA, Palmer MS and McMichael AJ (1990) Human trophoblast and the choriocarcinoma cell line BeWo express a truncated HLA class I molecule Journal of Immunology 144 731-735

Fillion C, Chaouat G, Reinaud P, Charpigny JC and Martal J (1991) Immunoregulatory effects of ovine trophoblastin protein (oTP): all five isoforms suppress PHA-induced lymphocyte proliferation Journal of Reproductive Immunology $19237-249$

Gambel P, Croy BA, Moore WD, Hunziker RD, Wegmann TG and Rossant J (1985) Characterization of immune effector cells present in early murine decidua Cellular Immunology 93 303-314

Gendron RL and Baines MG (1988) Infiltrating decidual natural killer celis are associated with spontaneous abortion in mice Cellular Immunology 113 261-267

Hunt JS, Fishback JL, Andrews GK and Wood GW (1988) Expression of class I HLA genes by trophoblast cells: analysis by in situ hybridization Journal of Immunology 140 1293-1299

King A and Loke YW (1990) Human trophoblast and JEG choriocarcinoma cells are sensitive to lysis by IL-2-stimulated decidual NK cells Cellular Immunology 129 435-448

King A and Loke YW (1991) On the nature and function of human uterine granular lymphocytes Immunology Today 12 432-435

King A, Wheeler R, Carter NP, Francis DP and Loke YW (1992) The response of human decidual leukocytes to IL-2 Cellular Immunology 141 409-421

Kolb JP, Chaouat G and Chassoux D (1984) Immunoactive products of placenta. III. Suppression of natural killing activity Journal of Immunology $\mathbf{1 3 2}$ 2305-2310

Lala PK, Scodras JM, Graham CH, Lysiak JJ and Parhar RS (1990) Activation of maternal killer cells in the pregnant uterus with chronic indomethacin therapy, IL-2 therapy, or a combination therapy is associated with embryonic demise Cellular Immunology 127 368-381

Lambert RD, Roy R, Morin C. Beaudoin J, Langlais J and Pandian AMC (1989a) Modulation of the immunosuppressive activities by blastocoelic fluid during rabbit pregnancy Journal of Reproductive Immunology 15 257-268

Lambert RD, Gosselin S, Pothier F, Morin C, Veilleux R, Roy M and Fortier MA (1989b) Rabbit blastocoelic fluid regulation of tumor-cell proliferation in vitro Internation Journal of Cancer 44 524-528

Leonard WJ, Depper JM, Crabtree GR, Rudikoff S, Pumphrey J, Robb RJ, Krönke M, Svetlik PB, Peffer N], Waldmann TA and Greene WC (1984) Molecular cloning and expression of cDNAs for the human interleukin-2 receptor Nature 311 626-631

Leonard WJ, Krönke M, Peffer NJ, Depper JM and Greene WC (1985) Interleukin 2 receptor gene expression in normal $\mathrm{T}$ lymphocytes Proceedings of the National Academy of Sciences, USA 82 6281-6285

Lin PY, Joag SV, Young JDE, Chang YS, Soong YK and Kuo TT (1991) Expression of perforin by natural killer cells within first trimester endometrium in humans Biology of Reproduction 45 698-703

Lotz M, Jirik F, Kaboudiris P, Tsoukas C, Hirano T, Kishimoto T and Carson DA (1988) B cell stimulating factor $2 /$ interleukin 6 is a costimulant for human thymocytes and $\mathrm{T}$ lymphocytes Journal of Experimental Medicine 167 1253-1258

Lu CY, Changelian PS and Unanue ER (1984) $\alpha$-Fetoprotein inhibits macrophage expression of la antigens Journal of Immunology 132 1722-1727
Morin C, Langlais J and Lambert RD (1992) Possible implication of lysophosphatidylcholine in cell fusion accompanying implantation in rabbits Journal of Reproduction and Fertility 96 827-836

Newton GR, Vallet JL, Hansen PJ and Bazer FW (1989) Inhibition of lymphocyte proliferation by ovine trophoblast protein- 1 and a high molecular weight glycoprotein produced by the peri-implantation sheep conceptus American Journal of Reproductive Immunology 19 99-107

Nicholas NS and Payani GS (1985) Inhibition of interleukin-2 production by retroplacental sera: a possible mechanism for human fetal allograft survival American Journal of Reproductive Immunology 9 6-11

Niwano Y, Hansen TR, Kazemi M, Malathy PV, Johnson HD, Roberts RM and Imakawa K (1989) Suppression of T-lymphocyte blastogenesis by ovine trophoblast protein- $I$ and human interferon- $\alpha$ may be independent of interleukin-2 production American Journal of Reproductive Immunology 20 $21-26$

Pandian AMC, Lambert RD and Roy R (1988) Immunosuppressive effects of rabbit blastocoelic fluid and embryo culture medium Journal of Reproductive Immunology 13 221-234

Paul WE and Ohara J (1987) B-cell stimulatory factor-1/interleukin 4 Annual Review of Immunology 5 429-459

Redman CWG, McMichael AJ, Stirrats GM, Sunderland CA and Ting A (1984) Class I major histocompatibility complex antigens on human extra-villous trophoblast Immunology $52 \quad 457-468$

Reem GH and Yeh NH (1984) Interleukin 2 regulates expression of its receptor and synthesis of gamma interferon by human $\mathrm{T}$ lymphocytes Science $\mathbf{2 2 5}$ $429-430$

Saito S, Hashimoto H, Yonemasu K and Ichijo M (1990) Pregnancy zone protein inhibits production of interleukin-2 but does not affect interleukin-2 receptor expression on $T$ cell activation Journal of Reproductive Immunology 17 $115-126$

Schlafke S and Enders AC (1975) Cellular basis of interaction between trophoblast and uterus at implantation Biology of Reproduction 12 41-65

Segerson EC and Libby DW (1990) Interaction of bovine uterine luminal protein with interleukin-2 and the interleukin-2 receptor of $T$ lymphocytes Biology of Reproduction 43 619-628

Skibin A, Quastel MR, Kuperman O and Segal S (1989) Suppression of lymphocyte activation by a soluble factor released from the human placental chorionic membrane: chemical analysis and functional characterization American Journal of Reproductive Immunology 19 85-91

Slapsys RM and Clark DA (1982) Active suppression of host-vs-graft reaction in pregnant mice. IV. Local suppressor cells in decidua and uterine blood Journal of Reproductive Immunology 4 355-364

Smith KA (1988) Interleukin-2: inception, impact, and implications Science $\mathbf{2 4 0}$ 1169-1176

Stewart IJ (1991) Granulated metrial gland celis; pregnancy specific leukocytes? journal of Leukocyte Biology 50 198-207

Takeshita T, Goto Y, Nakamura M, Fujii M, Iwami M, Hinuma $Y$ and Sugamura K (1988) Phorbol esters can persistently replace interleukin-2 (IL-2) for the growth of an interleukin-2-dependent T-cell line Journal of Cellular Physiology $136319-325$

Tiersh TR, Chandler RW, Watchtel SS and Elias S (1989) Reference standards for flow cytometry and application in comparative studies of nuclear DNA content Cytometry 10 706-710

Watson ED (1990) Suppression of lymphocyte reactivity by culture supernatant from horse embryo and endometrium Biology of Reproduction 42 294-300

Welte K, Andreef M, Platzer E, Holloway K, Rubin BY, Moore MAS and Mertelsmann R (1984) Interleukin 2 regulates the expression of TAC antigen on peripheral blood $\mathrm{T}$ lymphocytes Journal of Experimental Medicine $\mathbf{1 6 0}$ 1390-1403

Yoshida M, Kanzaki H, Kariya M, Emi N, Imai K, Okamoto N, Uchida A, Kasakura S and Mori T (1990) Reduction of interleukin-2-receptor expression on retroplacental blood lymphocytes in human pregnancy American Journal of Reproductive Immunology 22 1-3

Yoshimura N, Matsui S, Hamashima T, Lee CJ, Ohsaka Y, Hirakawa K and Oka T (1991) Prolongation of renal allograft survival in the rat treated with amniotic fluid Transplantation 52 540-545

Zheng LM, Ojicus DM and Young JD-E (1993) Perforin-expressing cells during spontaneous abortion Biology of Reproduction 48 1014-1019 